DOI: $10.35643 /$ Info.26.1.11

Dossier temático: Ética de la Información

\title{
Digital Ethics by Process? Technical conflicts and policy ethics committees in Europe[1]
} ¿Ética digital por proceso? Conflictos técnicos y comités de políticas de ética
en Europa

Ética digital por processo? Conflitos técnicos e comitês de política de ética na Europa

Tobias Keber ${ }^{\mathrm{a}}$ a Professor Dr. Tobias Keber, Institute for Digital Ethics (IDE), Faculty Electronic Media,
Stuttgart Media University, Stuttgart, Baden-Württemberg, Germany. ORCID: 0000-0001-5469-
1677. Correo electrónico: keber@hdm-stuttgart.de

\begin{abstract}
The paper examines the work of (policy) ethics committees in Europe. The different mandates and outputs of the various working groups are discussed. The committees' work sometimes does not fulfil the principle "ethics by design", although exactly this is required by technology design. Ethics by design as a principle for the institutional design of policy ethics committee should be provided for as an indispensable minimum organisational standard.
\end{abstract}

Keyword: POLICY ETHICS COMMITTEE; DIGITAL ETHICS; ETHICS BY DESIGN; EUROPE

\section{Resumen}

El documento examina el trabajo de los comités de ética (de políticas) en Europa. Se discuten los diferentes mandatos y productos de los distintos grupos de trabajo. El trabajo de los comités a veces no cumple con el principio de "ética desde el diseño", aunque el diseño tecnológico lo exige exactamente. La ética por diseño como principio para el diseño institucional del comité de ética de políticas debe establecerse como un estándar organizativo mínimo indispensable.

Palabras claves: COMITÉ DE POLÍTICAS DE ÉTICA; ÉTICA DIGITAL; ÉTICA POR DISEÑO; EUROPA

\section{Resumo}


O documento examina o trabalho de comitês de ética (política) na Europa. Os diferentes mandatos e resultados dos vários grupos de trabalho são discutidos. $\mathrm{O}$ trabalho dos comitês às vezes não cumpre o princípio "ética por design", embora exatamente isso seja exigido pelo design de tecnologia. A ética desde a concepção como um princípio para a concepção institucional do comitê de política de ética deve ser considerada um padrão organizacional mínimo indispensável.

Palavras-chave: COMITÊ DE POLÍTICA DE ÉTICA; ÉTICA DIGITAL; ÉTICA POR DESIGN; EUROPA

\begin{tabular}{ll} 
Received: & $20 / 08 / 2020$ \\
Accepted: & $02 / 05 / 2021$ \\
\hline
\end{tabular}

\section{Rise of (digital) ethics}

Spotlight on ethics: In 2019, "digital ethics" was declared to be one of the ten most important technology trends. [2] No question: ethics has a momentum, as also proved by the circumstance that the initiative Algorithm Watch compiled over 80 papers with guidelines for a wide range of actors (including companies, associations, non-governmental organisations, civil society, science) in the last year on the topic of "AI ethics" alone. [3]

Against the backdrop of the plethora of questions implied by mechanisation and digitalisation, policy has newly discovered ethics as a challenge management tool. "Rediscovered" would be more accurate, as a "higher moral need" in view of modern technologies (cf. Höffe, 1993) has been long discussed, along with the role of ethics (cf. Wiener, 1963; cf. Weizenbaum, 1978; 1987; 1988) [4]. Almost 20 years ago, Rafael Capurro, who introduced and shaped the term "Digitale Ethik" (digital ethics) (cf. Capurro, 2009) [5] in the German-speaking world, wrote:

Modern science and technology challenge basic philosophic assumptions and provoke thus directly or indirectly a crisis, or at least a basic insecurity, with regard to moral standards that were either sanctioned by law or remained tacit moral presuppositions. The rise of ethics within the political arena may be interpreted as a symptom of a moral crisis within modern societies (cf. Capurro, 2005) 
The new trend in politics of "placing more emphasis on ethics" (Wischmeyer \& Herzog, 2019) is neither entirely new nor singular. Ethical questions are known in many scientifically and technologically complex areas. [6]

\section{Ethicisation of technological conflicts}

As regards the technological conflicts of the present, ad hoc committees were contrasted with and/or added to the already-established ethics committees both on a European and a national level. It is true that these draw terminology from various fields, namely data ethics, algorithm ethics or AI ethics. The boundaries of these sub-disciplines are in any case permeable and can certainly be gathered under the umbrella of digital ethics.

Is the (re)strengthened role of ethics so great that one can speak of an ethicisation of technological conflicts (cf. Bogner, 2009; 2011)? [7] In actual fact, lawmakers have broadly shied away up to now, in view of what is seen as their (even in the light of the precautionary principle) inadequate knowledge base, from (prematurely) imposing "hard" regulations in the area of new technologies. The approach of using policy ethics committees gives the impression that a "softer" instrument of technological governance, independent from the law [8] is available, such that some people speak in this context of "soft law". [9] In actual fact, the role, justification and operationalisation of Digital Ethics in the multidimensional space of Technological Governance remain unclear. Namely, the exact border between law and ethics [10] is called into question by the use of numerous policy ethics committees.

\section{Ethics and institutionalisation}

Does the proliferation of committees in policy roles entail a trivialisation of ethics (cf. Sommermann, 2003)? Or, asked from a legal perspective: Isn't the legislator ducking (parliamentary democratic) responsibility, because the legislative branch simply cannot "outsource" or (externally) delegate the factual and knowledge base which is the basis of their assessment prorogative? [11] On the other hand, it could be argued that the institutionalisation of ethical, extra-parliamentary expertise is the fulfilment of the "principle of accountability" (borne by multiple 
shoulders) (cf. Jonas, 1984) and therefore permissible exploration of the subject area. More simply put, and to attempt and image from sport: the use of committees is merely the legislative warm-up phase [12] and is an integral part of the political process, in that ethical committees (pre-) structure the debate without prejudicing results (cf. Dederer, 2013).

\section{Ethics and law}

If each individual guideline, declaration or recommendation of the various ethics committees seems discussion-worthy in its own right, the more exciting question of whether there are contradictory statements in the interplay of various papers and how to deal with these has rarely been asked [13]. It seems worthwhile to compare the respective mandate, the way of working and the results of the various committees in order to work out commonalities in such a way that possible disharmonies in the guidelines canon of the working groups coordinated across levels.

To ask specifically: If an ethics committee deployed to tackle a particular question recommends particular legislative measures after ethically reflecting on the implications of a socio-technical system, the (admittedly naive) expectation would be that a committee deployed differently but with one eye on the same subject matter could come to a completely different result. This is certainly the case if one does not wish to accuse ethics of arbitrariness and regards it as permissible at all for an ethics council to work out specific recommendations, instead of merely pointing up (several) action options based on the various ethical theories (and perhaps their consequences). The law is less suspicious of methodological arbitrariness than ethics is. But what understanding of the boundary between the disciplines of law and ethics do the various ethics committees use as a basis? Does it depend on differences at all?

The irrelevance of a synoptic view of the variety of committees currently to be observed can be justified by merely referring to the fact that recommendations (by whichever ethics council) are non-binding and the question of mutual congruence therefore does not arise. Soloists alone don't make an orchestra. But nonbindingness now works like this. If an expert committee appointed under public 
law makes specific recommendations in a comprehensively justified paper, can the legislative branch actually ignore these guardrails (without political costs, completely or at least in parts) (cf. Wischmeyer \& Herzog, 2019)?

The questions which arise thus give reason to briefly recapitulate the important ethics committees, their respective mandates, the approach and core content of the various papers adopted.

\section{Ethics committees on the European level}

\section{EGE and declaration on AI, robotics and "autonomous" systems}

Under the aegis of the European Union, ethical questions are primarily the responsibility of the European Group on Ethics [14] in Science and New Technologies (EGE). The committee, founded in 1991 as an independent advisory committee to the President of the European Commission is currently working, among other things, on the topics of genome editing, artificial intelligence (AI) and the future of work. The 15 members of the interdisciplinary EGE are appointed based on their specialist knowledge in the areas of law, natural and social sciences, philosophy and ethics. The task and approach of the committee, whose mandate was last extended by 5 years in 2016, is governed by a resolution of the Commission. [15] According to this, opinions and recommendations should generally be accepted unanimously, but dissenting opinions may be listed as a “minority opinion". Discussions are generally confidential according to Article $5(10)$ of the resolution of the Commission. It is also prescribed that a strictly balanced representation of women and men must be ensured, and balanced distribution according to age groups and geographical origin must be duly considered (Article 4(6a) of the Commission Resolution).

On 09/03/2018, the EGE published its declaration on artificial intelligence, robotics and "autonomous" systems. [16] This a rather short, very basic document, which points up the fundamental questions and frames central terms such as autonomy. At the end of the document, there is a catalogue of ethical principles based "on the basic values anchored in the EU Treaties and in the Charter of Fundamental Rights of the European Union". The document is highly abstract, and gives no concrete recommendations. 


\section{HLEG and Ethics Guidelines on Artificial Intelligence}

The High-Level Expert Group (HLEG) for Artificial Intelligence (AI), established with 52 members by the European Commission in June 2018, gives much more specific information. [17] The committee's line-up came in for criticism, as one could regard up to $50 \%$ of its members (depending on how exactly one classifies each person's professional background) as close to business. [18] The HLEG presented its ethical guidelines in April 2019, after it gave a first draft in December 2018 for public comment (open consultation). A communication of the commission [19] describes its approach as based on the work of the $E G E$, oriented by "similar efforts in this area", whereby references are made to the $E G E^{\text {‘s }}$ declaration on artificial intelligence, as well as international papers.

In the HLEG's Ethics Guidelines on Artificial Intelligence [20], 7 central principles are formulated for designing AI systems so as to be "trustworthy". According to the document, the foundation should initially be a triad formed of legality, compliance with ethical principles and robustness, whereby the latter is addressed not only from a technical but also a societal perspective. In this context, the authors also present their basic understanding of the relationship between law and ethics, and much of the document is given over to which ethical principles can be derived from fundamental rights (which in this direction is quite notable) and where ethics has a supplementary function going beyond law.

In parallel to the guidelines, the HLEG also presented a definition of artificial intelligence which will be useful for interdisciplinary discourse [21] and with the Policy and Investment Recommendations [22] presented a total of 33 recommendations "that can guide Trustworthy AI towards sustainability, growth and competitiveness". The HLEG thus aims not only for conceptualisation and specific recommendations, but rather is also aiming for terminology which can be operationalised. [23]

\section{EDPS and report of the Ethics Advisory Group}

Long before the HLEG was mandated, the European Data Protection Supervisor $(E D P S)$ dealt with the topic of ethics. Against the backdrop of its opinion 
“Toward a New Digital Ethics" in 2015 [24], a 6-person, mostly academic Ethics Advisory Group [25] was appointed in January 2016.

The Ethics Advisory Group submitted its report in 2018. [26] The interplay of law and ethics and the various views defended are addressed broadly in this report, whereby the shared point of departure for both disciplines are fundamental values, which in turn have their roots in human dignity. Starting from this point, ethics on the application level should be responsible for assessing algorithmic profile formation technologies, for example. Overall, the EDPS paper raises (fundamental) questions with broad conceptualisation, rather than making specific action recommendations.

\section{Ethics committee and ethics by design}

What is left in the synopsis?

\section{Disunited in diversity}

The ethics committees described turn out to be disunited in diversity. This is true not only as regards specific discrepancies in content, but also:

- the basic approach (more descriptive or more normative),

- the conception of technology used as a basis (which is normally not discussed and/or outlined further at all),

- the understanding of the relationship between law and ethics used as a basis, as well as

- rules for determining the make-up of the committee (including gender parity) or

- the publicity of the committee's work.

Should there not be (to put it positively) at least an (organisational) minimal consensus for the work of ethics committees, which should cover not only ideological plurality, multidisciplinarity and gender parity also a commitment to the greatest possible degree of publicity (including on the level of individual work group meetings)? 
It would be beneficial, though difficult to formulate generally, the negative dimension of a minimal consensus, namely as regards the setting of external boundaries for permissible appointment of experts close to politics, the state, or business in ethics committees in the area of IT governance. In view of the approach of the various ethics committees, finally, one could ask whether the consensus principle which their work has often been based on is adequately conducive to the task of (in-depth) ethical reflection in the area of technological conflicts. Of course, in light of the results-oriented approach needed in the political framework, one cannot afford as much dissent as may be possible in (purely) academic discourse. Nevertheless, an explicitly documented "agree to disagree" within a policy ethics committee may be a valuable finding.

\section{Ethics by design}

Ethics by design as an orientation framework for a minimal consensus: A muchdiscussed subfield of Digital Ethics is currently "ethics by design". Just like the approach of value sensitive design, this fundamentally addresses those who have influence on the development of products and services. Ethical reflection is required across the whole product lifecycle, including the early conception phase. [27] Developers should ask themselves, for example, what will happen with their product (with consumers, but also persons who cannot or do not want to use the product), and what consequences its spread in society will have. Ethics by design has a product dimension (acceptance, sustainability of the product) and a process dimension (inclusion of all stakeholder directly and indirectly affected by the product). In its process dimension, ethics by design maps considerations which could be explained from the perspective of discourse ethics (cf. Alexy, 1987) or the principle of protection of fundamental rights by organisations and procedures. $[28]$

Ethics by design cannot only be about participative, inclusive product development, which primarily addresses commercial enterprises. The principle of including ethical reflection as early as possible, namely in its process dimension, should apply all the more to the institutional design of policy ethics committees. 
Rather, ethics by design should give rise to a universal minimum standard for the institutional design of policy ethics committees. A best practice example (and potential subject matter of a minimal consensus) with focus on the aspect of transparency of decision making can be found in the work of the Centre for Data Ethics and Innovation (CDEI) [29] in the United Kingdom. The CDEI documented its decision-making process (How did we form our final recommendations?) [30] on the topic of online targeting [31] in an exemplary manner. This is desirable for all policy ethics committees.

\section{Bibliography}

Alexy, R. (1978). Eine Theorie des Praktischen Diskurses (A Theory of Practical Discourse), In: Oelmüller (Eds.). Normenbegründung, Normendurchsetzung, Materialien zur Normendiskussion (Justification and Implementation of Norms, Materials on Discussion of Norms). Vol. 2, p. 22-58.

Bogner, A. (2011). Ethisierung von Technikkonflikten (Ethicisation of Technological Conflicts). Weilerswist: Velbrück Verlage

Bogner, A. (2009). Ethisierung und die Marginalisierung der Ethik, zur Mikropolitik des Wissens in Ethikräten (Ethicisation and the Marginalisation of Ethics, on the Micropolitics of Knowledge in Ethics Boards), Soziale Welt 60. p. 119-137 (121).

BVerfG (1979). Resolution of 20 December 1979 // BVerfGE 53, 30 (KKW Mülheim-Kärlich)

BVerfG (1983). Decision of 15 December 1983 = BVerfGE 65, 1 (census).

Capurro, R. (2009). Digital ethics, published in: The Academy of Korean Studies and Korean National Commission for UNESCO 2009 (Eds.). 2009 Global Forum Civilization and Peace, 207-216. Contribution accessible online at: http://www.capurro.de/DigitaleEthik.html.

Capurro, R. (2005). Ethics and Public Policy within a Digital Environment, The European Group on Ethics in Science and New Technologies (EGE) th the European Commission (Ed.). General Report 200-2005. Contribution available online at: http://www.capurro.de/ethicomp02.html

Dederer, H. G. (2013). Gerechtfertigter Einsatz von Ethikkommissionen Grundlagen und Grenzen. In: Vöneky, S., Beylage-Haarmann B.; Höfelmeier A. \& Hübler A.-K. (eds.) Ethik und Recht - Die Ethisierung des Rechts/Ethics and Law - The Ethicalization of Law. Beiträge zum ausländischen öffentlichen Recht und Völkerrecht (Veröffentlichungen 
des Max-Planck-Instituts für ausländisches öffentliches Recht und Völkerrecht), vol 240. Springer, Berlin, Heidelberg. https://doi.org/10.1007/978-3-642-37090-8 18

Ethics Advisory Group (2018). Report of 25/01/2018, document available at: https://edps.europa.eu/data-protection/our-work/publications/ethicalframework/ethics-advisory-group-report-2018 en.

European Data Protection Supervisor (2015). Opinion of 4/2015, Towards a New Digital Ethics, 11/09/2015, document available at:

https://edps.europa.eu/data-protection/ourwork/publications/opinions/towards-new-digital-ethics-data-dignityand en.

Floridi, L. (2018). Soft Ethics and the Governance of the Digital, Philosophy \& Technology, 31, p. 1-8.

Grimm, P., Keber, T.O., Zöllner, O. (2019). Digitale Ethik. Ditzingen: Reclam

Höffe, O. (1993). Moral als Preis der Moderne (Morals as the Price of Modernity). Frankfurt: Suhrkamp.

Jonas, H. (1984). Das Prinzip Verantwortung, Versuch einer Ethik für die technologische Zivilisation (The Accountability Principle, Attempting an Ethics for the Technological Civilisation), Frankfurt: Suhrkamp Verlag.

Keber, T. O. (2011). Chapter M. In: Dörr, D., Kreile, J., Cole, M (Eds.). Handbuch Medienrecht. Recht der elektronischen Massenmedien (Media Law Handbook - Law of Electronic Mass Media). 2. Ed. Frankfurt: Verlag Recht und Wirtschaft

Keber, T., Keppeler L. (2018). Artikel 25 DSGVO (Article 25 GDPR). In: Schwartmann, R., Jaspers, A., Thüsing, G., Kugelmann, G. (Eds.). Datenschutz-Grundverordnung mit Bundesdatenschutzgesetz (Heidelberger Kommentar) (General Data Protection Regulation with German Federal Data Protection Act (Heidelberg Commentary)), Article 25 GDPR.

Schliesky, U. (2019). Digitale Ethik und Recht (Digital Ethics and Law) In: NJW 2019, 3692-3697 (3693 et seq.).

Sommermann, K.-P. (2003). Ethisierung des öffentlichen Diskurses und Verstaatlichung der Ethik, Archiv für Rechts- und Sozialphilosophie. Ethicisation of Public Discourse and Nationalisation of Ethics, 89(1): 7586.

Yogeshwar, R. (2019). Maschinen herrschen (Machines dominate). Available at: https://yogeshwar.de/?p=2367

Wiener, N. (1993). God and Golem, Inc. Cambridge: MIT Press 
Weizenbaum, J. (1988). Kurs auf den Eisberg (Heading for the Iceberg)

Weizenbaum, J. (1987). Die Verantwortung de Einzelnen in der Diktatur der Technik (The Responsibility of the Individual in the Dictatorship of Technology). München: Piper Verlag.

Weizenbaum, J. (1978). Die Macht der Computer und die Ohnmacht der Vernunft. Frankfurt: Suhrkamp Verlag

Wischmeyer, T., Herzog, E. (2019). Digitale Ethik in der Demokratie. Digital Ethics in Democracy, 696 (696)

Zeng, Y. Lu, E., Huangfu, C. (2019). Linking Artificial Intelligence Principles, Proceedings of the AAAI Workshop on Artificial Intelligence Safety (AAAI-Safe AI 2019). Available at https://arxiv.org/pdf/1812.04814.

Zotti, S. (2009). Ethische Politikberatung (Ethical Policy Advice). In: Vöneky S., Beylage-Haarmann B., Höfelmeier A., Hübler A.-K. (Eds.). Ethik und Recht - Die Ethisierung des Rechts/Ethics and Law - The Ethicalization of Law. Beiträge zum ausländischen öffentlichen Recht und Völkerrecht. Veröffentlichungen des Max-Planck-Instituts für ausländisches öffentliches Recht und Völkerrecht, 99. Springer, Berlin, Heidelberg.

\section{Footnotes}

[1] The author would like to sincerely thank Dr Rafael Capurro for his many friendly and constructive discussions, suggestions and profound thoughts which this contribution is (partly) based on.

[2] Contribution can be found at: https://www.gartner.com/en/newsroom/pressreleases/2018-10-15-gartner-identifies-the-top-10-strategic-technology-trends-for2019.

[3] Information on the project "AI Ethics Guidelines Global Inventory" can be found at https://algorithmwatch.org/en/project/ai-ethics-guidelines-globalinventory/

[4] Norbert Wiener and Joseph Weizenbaum made early contributions regarding critical reflection on technology and its consequences for society.

[5] With regard to a conceptualization see: Grimm et al., 2019.

[6] Traditionally, this relates to the area of biotechnology and medical technology, but more recently, for example, to energy supply: Against the backdrop of the nuclear catastrophe of Fukushima and the discussion around the "nuclear 
moratorium", the "Ethics Committee for Secure Energy Supply" was founded in 2011 .

[7] Bogner understands ethicisation to mean "the problematisation of research and technologies as well as processing and regulation of these conflicts in ethical categories".

[8] "Technological Governance" can be defined by analogy to the term "Internet Governance" as the sum of principles, norms, rules, decision-making processes and programmes which all refer to the development of and interaction with technology, and which are worked out and applied by various actors (governments, the private economy and civil society). On "Internet Governance" see: Keber, 2011

[9] Along with the dogmatically dubious construction of "soft law", there should also be "soft ethics". see: Floridi, 2018

[10] For an in-depth treatment, see: Schliesky, 2019

[11] As an example, Horst Dreier warned of a "de-parliamentisation of political decisions" at the public meeting of the Nationaler Ethikrat, or National Ethics Council) (forerunner of the Deutscher Ethikrat, or German Ethics Council) in 2007. For evidence and more details, see: Zotti, 2009

[12] "Legislation preparatory to ethical discourse" in the systematisation according to Sommermann, 2003

[13] The initiative "Linking Artificial Intelligence Principles (LAIP)" aims to identify commonalities from numerous international documents from a wide range of actors (research institutes, government organisations and industry) around the topic of Artificial Intelligence and its connection to universal principles. The research results of the project can be found at http://linking-aiprinciples.org/, methodology and background are explained at Zeng, Lu \& Huangfu, 2019

[14] Information on the EGE is available online at: https://ec.europa.eu/info/research-and-innovation/strategy/support-policymaking/scientific-support-eu-policies/european-group-ethics-science-and-newtechnologies-ege en.

[15] Resolution (EU) 2016/835 of the Commission of 25 May 2016, which can be found at: https://eur-lex.europa.eu/legalcontent/EN/TXT/HTML/?uri=CELEX:32016D0835\&qid=1621609054386\&from $=\underline{E N}$

[16] EGE declaration can be found at: https://op.europa.eu/en/publication-detail//publication/dfebe62e-4ce9-11e8-be1d-01aa75ed71a1/language-de/format-PDF 
[17] Information on AI HLEG can be found at: https://ec.europa.eu/digital-singlemarket/en/high-level-expert-group-artificial-intelligence

[18] For criticism see, for example, Yogeshwar, 2019

[19] $\operatorname{COM}(2018) 237$ final, 25/04/2018, document can be found at: https://ec.europa.eu/transparency/regdoc/rep/1/2018/DE/COM-2018-237-F1-DEMAIN-PART-1.PDF

[20] The guidelines can be found at: https://ec.europa.eu/futurium/en/ai-allianceconsultation/guidelines\#Top

[21] Definition available online via: https://ec.europa.eu/futurium/en/ai-allianceconsultation/guidelines\#Top

[22] Policy recommendations can be found online at: https://ec.europa.eu/digitalsingle-market/en/news/policy-and-investment-recommendations-trustworthyartificial-intelligence

[23] The evaluation of the pilot phase is currently ongoing, within which affected interest groups (companies, research institutions and authorities) can give feedback on the "Trustworthy AI Assessment List" (specifying question catalogue at the level of the Ethics Guidelines on Artificial Intelligence) by 01/12/2019. Information on the process, the results of which may influence a legislative act on the European level can be found at: https://ec.europa.eu/commission/presscorner/detail/de/IP $19 \quad 1893$

[24] EDPS, opinion of 4/2015, Towards a New Digital Ethics, 11/09/2015, document available at: https://edps.europa.eu/data-protection/ourwork/publications/opinions/towards-new-digital-ethics-data-dignity-and en

[25] EDPS "ethics dossier" available at: https://edps.europa.eu/dataprotection/our-work/ethics en

[26] Ethics Advisory Group Report of 25/01/2018, https://edps.europa.eu/dataprotection/our-work/publications/ethical-framework/ethics-advisory-group-report2018 en

[27] A subfield of ethics by design is privacy by design, which was set down as a binding legal principle in Article 25 GDPR in the form of "data protection by design". See Keber \& Keppeler, 2018

[28] Cf. for example BVerfG, Resolution of 20 December 1979 = BVerfGE 53, 30 (KKW Mülheim-Kärlich); BVerfG, Decision of 15 December $1983=$ BVerfGE 65, 1 (census).

[29] For information on this policy ethics committee, see https://www.gov.uk/government/organisations/centre-for-data-ethics-andinnovation 
[30] According to the details on the website (Fn. 51), the basis for the CDEI's recommendation are as follows: "Our evidence base is informed by a landscape summary [...]; an open call for evidence; a UK-wide programme of public engagement; and a regulatory review of eight regulators. We have consulted widely in the UK and internationally with academia, civil society, regulators and the government. We have also held interviews with and received evidence from a range of online platforms in addition to advertising companies and industry bodies."

[31] Preparatory materials as well as the final report with recommendations can be found at: https://www.gov.uk/government/publications/cdei-review-of-onlinetargeting

\section{Author contribution}

The entirety of this manuscript was prepared by Tobias Keber.

\section{Editor's notes}

The editor responsible for the publication of this article was Rafael Capurro. 